Damian Kokoć

\title{
ARGUMENTY LOGICZNE W ŚREDNIOWIECZNEJ FILOZOFII I TEOLOGII MUZUŁMAŃSKIEJ: AL-GHAZALI, AWERROES, IBN AL-MUNADŻDŻIM
}

\section{WPROWADZENIE}

Średniowieczni filozofowie muzułmańscy bardzo chętnie sięgali do dorobku antycznych Greków - do ich pism z dziedziny medycyny, astronomii czy filozofii. Głównym kanałem przenikania filozofii greckiej do kultury muzułmańskiej była Syria. Tłumaczenia dokonywane przeważnie przez syryjskich mnichów (najczęściej nestorian), którzy obok pism Arystotelesa, Plotyna czy Proklosa, mieli dostęp także do dzieł Hipokratesa czy Galena, zaowocowały dużym zainteresowaniem dorobkiem antycznych filozofów ${ }^{1}$. Muzułmanie bardzo dużym szacunkiem i uznaniem darzyli w szczególności

${ }^{1}$ Bardzo ciekawą cechą charakterystyczną średniowiecznej filozofii muzułmańskiej jest łączenie myśli Arystotelesa z neoplatonizmem. Źródłem takiego podejścia była duża popularność Teologii Pseudo-Arystotelesa. Dzieło to przypisywane Stagirycie było faktycznie fragmentami Ennead Plotyna i Isagogi Porfiriusza. Dzięki autorytetowi, którym cieszył się Arystoteles wśród uczonych muzułmańskich za sprawą Teologii, przejęli oni również neoplatoński sposób ujmowania rzeczywistości. Zob. H. Corbin, Historia filozofii muzułmańskiej, przeł. K. Pachniak, Wydawnictwo Akademickie DIALOG, Warszawa 2005; O. Leaman, Krótkie wprowadzenie do filozofii islamu, przeł. T. Lipszyc, Fundacja Aletheia, Warszawa 2004; M. Gogacz, Dlaczego badamy średniowieczna filozofię arabska (przedmowa), [w:] Awicenna i średniowieczna filozofia arabska, red. A. Aduszkiewicz, M. Gogacz, Akademia Teologii Katolickiej, Warszawa 1982; A. Mrozek, Średniowieczna filozofia arabska, PWN, Warszawa 1967; J. Wronecka, Wstęp [w:] Ibn 'Arabi, Traktat o miłości, Wydawnictwo Naukowe PWN, Warszawa 1995. 
myśl Arystotelesa ${ }^{2}$. Obok jego koncepcji fizycznych, biologicznych czy metafizycznych, z dużym zainteresowaniem studiowali jego pisma logiczne. Muzułmanie bardzo szybko zauważyli, że logika stanowi bardzo praktyczne narzędzie i może znaleźć zastosowanie we wszelkiego rodzaju dyskusjach teologicznych oraz filozoficznych. Zaczęli ją więc wykorzystywać w kontaktach z wyznawcami innych niż islam religii, w celu przekonania ich drogą rozumową do przyjęcia islamu, jak również w sporach intelektualnych toczonych wewnątrz samego islamu. Odwołanie się do arystotelesowskiej logiki wynikało między innymi z tego, że ludy podbite podczas szybkiej ekspansji muzułmańskiej, jaka miała miejsce w pierwszych wiekach hidżry ${ }^{3}$, znajdowały się przeważnie na wyższym poziomie rozwoju cywilizacyjnego niż Arabowie. Dlatego przekonując do prawdziwości nowej religii, muzułmanie musieli zacząć używać języka, który byłby zrozumiały dla ich rozmówców - a był to język logiki ${ }^{4}$.

W moim artykule skupię się na trzech przykładach zastosowania przez myślicieli muzułmańskich logiki w sporach teologicznych i filozoficznych. Pierwszym z nich będzie polemika Al-Ghazalego z isma'ilitami, drugim - odparcie przez Awerroesa zarzutów pod adresem filozofii, które

${ }^{2}$ Według jednej z anegdot, kalif Al-Mamun miał sen, w którym ukazał mu się Arystoteles, który przekazał władcy, że jego nauki nie są sprzeczne z islamem. W wyniku tego wydarzenia, kalif wysłał posłów do cesarza bizantyjskiego Leona Armeńczyka z prośbą o przekazanie mu dzieł antycznych myślicieli. Cesarz przychylił się do tej prośby. Otrzymane księgi stanowiły istotny składnik biblioteki założonego przez Al-Mamuna w Bagdadzie w 830 r. Bajt al-Hikma, czyli Domu Mądrości, ważnego ośrodka naukowego. Zob. A. Aduszkiewicz, Przegląd ważniejszych osób, poglądów $i$ wydarzeń $w$ średniowiecznej filozofii arabskiej, [w:] Awicenna..., dz. cyt.

${ }^{3}$ Hidżra oznacza „wywędrowanie”, „emigracja”. Pojęcie to odnosi się do opuszczenia przez Muhammada i jego zwolenników Mekki i udania się do Medyny, które miało miejsce 16 czerwca $622 \mathrm{r}$. Muzułmanie uznają to wydarzenie za początek nowej ery. Ponieważ kalendarz muzułmański jest kalendarzem księżycowym, jest on krótszy od słonecznego i zawiera 354 dni. Aby przeliczyć daty, należy zastosować następujący wzór: $\mathrm{S}=\mathrm{H}-(3 \mathrm{H} / 100)+622$; gdzie S - rok słoneczny, $\mathrm{H}$ - rok hidżry. Zgodnie z tym wzorem, rok 2011 Anno Domini odpowiada rokowi 1432 Anno Hidżra. Zob. J. Danecki, Podstawowe wiadomości o islamie, t. I, Wydawnictwo Akademickie DIALOG, Warszawa 2002; tenże, Kultura islamu - słowniki, Wydawnictwa Szkolne i Pedagogiczne, Warszawa 1997; J. Bielawski, Islam, Krajowa Agencja Wydawnicza, Warszawa 1980.

${ }^{4}$ Zob. H. Corbin, dz. cyt.; O. Leaman, dz. cyt., passim. 
sformułował Al-Ghazali. Ostatnim natomiast będzie zastosowanie logiki przez Ibn al-Munadżdżima w celu nakłonienia jego dwóch przyjaciół chrześcijan do przyjęcia prawdziwości islamu.

\section{SPORY TEOLOGICZNE: AL-GHAZALI I ISMA'ILICI}

Abu Hamid al-Ghazali w wielu swoich dziełach prowadził ostrą polemikę $\mathrm{z}$ isma'ilitami, mniejszościowym odłamem $\mathrm{w}$ ramach szyizmu ${ }^{5}$. Jednym $\mathrm{z}$ nich jest traktat Sprawiedliwa waga, który napisany został $\mathrm{w}$ konwencji dialogu autora $\mathrm{z}$ nieznanym $\mathrm{z}$ imienia zwolennikiem tego ruchu. Al-Ghazali ${ }^{6}$ wykorzystuje w nim rozumowanie oparte na logice w celu wykazania błędności poglądów swojego adwersarza. Obok systematycznego wykładu zasad s praw i ed liwej wag i, z kart tego tekstu przebija się także osobista niechęć tego muzułmańskiego myśliciela do isma’ilitow. Osoba, z którą dyskutuje, przedstawiona jest jako słabo wykształcona i nie posiadająca zdolności polemicznych.

Jak zostało wspomniane, w tekście tym Al-Ghazali prezentuje pięć tak zwanych zasad sprawiedliwej wagi, które mają zapewnić człowiekowi uzyskanie wiedzy pewnej. Są to:

- zasada równowagi, która dzieli się na wielką, średnią oraz małą,

- zasada współistnienia,

- zasada opozycji.

Zdaniem tego filozofa wszystkie one mają Boskie pochodzenie i zostały przekazane ludziom za pośrednictwem proroków. Twierdzi on, że każda z tych zasad została opisana w Koranie, jak pisze:

${ }^{5} \mathrm{Na}$ temat szyizmu i isma'ilitów oraz ich doktryny zob. H. Corbin, dz. cyt.; J. Danecki, dz. cyt., K. Pachniak, Doktryny isma'ilickie w dziełach Al-Kirmaniego, Wydawnictwo Akademickie DIALOG, Warszawa 2004; D. Kokoć, Wpływ spuścizny filozofii greckiej na kulturę islamu, „Przegląd Religioznawczy” 2010, nr 4 (238), s. 131-140; tenże, Elementy racjonalności w mistyce muzułmańskiej, „Racjonalia. Z punktu widzenia humanistyki” 2011, nr 1, s. 55-68.

${ }^{6} \mathrm{~W}$ artykule przedrostek ,al-" zapisuję małą literą, gdy podaję imię danego filozofa w pełnym brzmieniu, np. Abu Hamid al-Ghazali. Natomiast gdy używam ostatniego członu imienia, np. Al-Ghazali, wtedy przedrostek ten piszę wielką literą. Przyjmując taką metodę, kierowałem się sposobem zapisu, jaki stosowali w swoich monografiach m.in. Katarzyna Pachniak i Janusz Danecki (zob. dz. cyt.) 
To pięć reguł (mawazin), które Bóg objawił w Księdze [tj. w Koranie - D.K.] i nauczył swoich proroków, jak się nimi posługiwać. Zatem ten, który uczy się od proroka Boga i posługuje Bożą Wagą, kroczy ścieżką, a ten, który z niej zbacza ku rajowi (opinii) i kijasowi (analogii), błądzi i ginie ${ }^{7}$.

Ta Boska legitymizacja ma być niepodważalnym gwarantem, że są one niezawodne, a poznanie, do którego się za ich pomocą dochodzi, jest absolutnie pewne.

Wielka reguła równowagi zbudowana jest z dwóch przesłanek oraz z wynikającego z nich wniosku. Pierwszą z nich przyjmuje się na zasadzie konwencji czy też powszechnego przekonania, że jest ona prawdziwa. Druga ma natomiast charakter empiryczny. Zdaniem Al-Ghazalego jedynie przesłanka otrzymana drogą empiryczną ma takie właściwości, że może być uznana za prawdziwą sama przez siebie. Taki atrybut nie przysługuje natomiast ani przesłance konwencjonalnej, ani wnioskowi. Wniosek staje się oczywisty tylko i wyłącznie dzięki przesłankom. Autor Sprawiedliwej wagi stwierdza, że jest to niezawodny schemat wnioskowania, gdyż jego cechą konstytutywną jest to, że gdy uznamy prawdziwość przesłanek, to z konieczności musimy przyjąć także prawdziwość wniosku, który z nich wynika.

Średnia reguła równowagi odróżnia się od wielkiej reguły tym, że któraś z dwóch przesłanek ma postać negatywną. Wnioskowanie oparte na niej polega na tym, że rozpatrując dwa obiekty, jednemu z nich przypisuje się jakiś konkretny atrybut, natomiast odmawia się go drugiemu z nich. Ów atrybut pełni wtedy rolę elementu, który pozwala nam odróżniać od siebie rozpatrywane przedmioty.

Jeśli chodzi o małą regułę równowagi, to zasadza się ona z kolei na tym, że jednej rzeczy przypisuje się dwa atrybuty. Tym, co powinno je cechować,

${ }^{7}$ A.H. al-Ghazali, Sprawiedliwa waga. Ratunek przed zabłądzeniem, przeł. K. Pachniak, Wydawnictwa Uniwersytetu Warszawskiego, Warszawa 2008, s. 54. Raj (samodzielna opinia uczonego, którą kieruje się wydając swoje sądy) oraz kijas (wydawanie wyroku poprzez porównanie rozpatrywanego zagadnienia do wcześniej rozstrzygniętej, analogicznej sytuacji) należą do metod stosowanych przez muzułmańskich prawników. Raj (opinia) jest charakterystyczny dla szkoły hanifickiej, prawnicy szkoły malikkckiej odwoływali się często do raju (opinii) Malika Ibn Anasa, twórcy tej szkoły. Kijas (analogia) z kolei to metoda stosowana w szkole szafi'ickiej. Zob. J. Danecki, dz. cyt. 
jest to, że ich zakresy znaczeniowe powinny mieć pewną cześć wspólną. Według Al-Ghazalego reguły równowagi, we wszystkich trzech odmianach, mają postać sylogizmu.

Rozumowanie oparte na regule współistnienia bazuje na prawach modus ponendo ponens lub modus tollendo tollens. Podobnie jak we wcześniejszych przypadkach, tak i tutaj przy wnioskowaniu wykorzystuje się dwie przesłanki. Pierwsza z nich ma formę implikacji, która składa się z elementu warunkującego, który jest poprzednikiem implikacji, oraz elementu warunkowanego, czyli następnika implikacji. Druga przesłanka jest natomiast albo negacją warunkującego albo afirmacją tego, co jest warunkowane:

Oto definicja tej reguły: wszystko, co jest niezbędne jakieś rzeczy, dotyczy jej we wszystkich aspektach. Zatem negacja tego, co konieczne, warunkuje (lazim) nieodzownie negację tego, co jest warunkowane (malzum), a z istnienia warunkowanego wynika koniecznie istnienie tego, co warunkuje. Zaprzeczenie temu, co jest warunkowane, a potwierdzenie istnienia tego, co warunkuje, nie zawiera żadnej konkluzji i należy do reguły diabła, którymi niektórzy zwolennicy talimu posługują się do mierzenia poznania ${ }^{8}$.

O samych regułach diabła pisze następująco:

Wiedz, że do każdej pochodzącej z Koranu zasady, którą przytoczyłem, diabeł dorzucił związaną z nią regułę. Dodaje się ją do tej prawdziwej, aby się z nią zmierzyć i wyprowadzić ludzi na manowce? ${ }^{9}$.

Reguła opozycji z kolei może zostać użyta, gdy rozpatrywany obiekt może być przypisany do dwóch zbiorów. Gdy zanegujemy, że znajduje się on w pierwszym z nich, to z konieczności pociąga to potwierdzenie, że należy go przypisać do drugiego zbioru. Ważnym zastrzeżeniem dotyczącym tej reguły jest to, że można ją stosować tylko wtedy, gdy mamy do czynienia ze zbiorami określonymi, czyli - gdy uwzględnia się wszystkie możliwe zbiory, do których można przypisać omawiany przedmiot.

Al-Ghazali zarzuca isma'ilitom, że dowodząc prawdziwość swojej doktryny, w szczególności koncepcji talimu (autorytatywnego nauczania

\footnotetext{
${ }^{8}$ A.H. al-Ghazali, Sprawiedliwa..., dz. cyt., s. 79

9 Tamże, s. 89.
} 
imama), posługują się tak zwanymi reguła mi diabła, czyli sofizmatami. Wynika to ze złego wykorzystania małej reguły równowagi. Jego zdaniem, zwolennicy tego nurtu szyizmu zamiast dwóm atrybutom przypisać jeden przedmiot, to dwóm przedmiotom nadają jeden atrybut. Ich rozumowanie przebiega następująco: zarówno talim, jak i prawdę cechuje to, że są jedne. Więc skoro i talim i prawda są jedne, to talim musi być z konieczności prawdziwy, co jest, zdaniem Al-Ghazalego, oczywistym fałszem.

W opinii tego muzułmańskiego teologa, metoda talimu jest nie tylko nieprawomocna, ale jest także wysoce niepraktyczna. Wynika to z tego, że zanim dotrze się do imam lub jego wysłannika i uzyska odpowiedź na dręczące nas pytania, to czas na podjęcie decyzji czy działania może dawno minąć. Zdaniem Al-Ghazalego człowiek powinien kierować się samodzielnym rozumowaniem, które oparte ma być o reguły sprawiedliwej wagi. W innym swoim dziele, Ratunek przed zabłądzeniem, Al-Ghazali stwierdza, że ślepe kierowanie się talimem powoduje również to, że isma'ilici szukają nauczyciela, ale gdy go odnajdą, to nie są $\mathrm{w}$ stanie niczego się od niego nauczyć:

\begin{abstract}
Zadziwiające doprawdy, że człowiek traci życie na poszukiwanie wiedzy, a następnie zadawala się wiedzą tak marną i niepewną [wiedzą pochodzącą z talimu - dop. D.K], wyobrażając sobie jednocześnie, że właśnie osiągnął jej szczyty. [...] Ich osiągnięcia [tj. isma'ilitów - dop. D.K.] rozczarowują zwykłego człowieka i świadczą o słabości umysłu w dowodzeniu potrzeby istnienia autorytatywnego nauczyciela ${ }^{10}$.
\end{abstract}

Innym przykładem sofistycznego rozumowania isma'ilitów jest to, że operują alternatywą, że prawdę można poznać albo za pomocą talimu, albo raju (opinii uczonych). Zgodnie z regułą opozycji, negacja jednego z członów alternatywy pociąga za sobą potwierdzenie prawdziwości drugiego. Isma'ilici dowodzą dalej, że raj jest fałszywy, gdyż uczeni głoszą często sprzeczne sądy na temat tych samych zagadnień, zatem talim musi być prawdziwy. Według Al-Ghazalego jest to błędne wykorzystanie owej reguły, gdyż - jak już zostało wspomniane - wnioskowanie na jej bazie jest prawomocne tylko wtedy, gdy mamy do czynienia ze zbiorem określonym. W przypadku wnioskowania isma'ilitów mamy do czynienia ze zbiorem,

${ }^{10}$ Tamże, s. 162. 
który nie jest określony, gdyż pomijają oni trzecią możliwość, że do prawdy można dojść za pomocą zarówno raju, jak i talimu.

Al-Ghazali w swoich tekstach polemicznych zarzucał również filozofom, że nie stosują w swoich dociekaniach metafizycznych tych samych kryteriów, które postulują na gruncie logiki. Konsekwencją takiego postępowania jest to, że ich systemy stają się wewnętrznie sprzeczne. Wnioski, do jakich dochodzą w wyniku rozważań metafizycznych, oparte są - według niego nie na przesłankach pewnych, a jedynie na domysłach. Prowadzi to filozofów do głoszenia wielu błędnych tez, które powodują, że powinni być oni uznani za winnych grzechu bezbożności.

\section{SPÓR FILOZOFII Z TEOLOGIĄ: AWERROES ODPIERA ZARZUTY AL-GHAZALEGO}

W jednym ze swoich głównych dzieł, Traktacie rozstrzygajacym, Awerroes podejmuje się zadania odparcia oskarżeń, jakie wysunął Al-Ghazali wobec filozofów. W tym celu wykorzystuje on logikę, aby lepiej uzasadnić swoje argumenty. Przede wszystkim podkreśla on, że filozofia nie jest sprzeczna z religią i Prawem wynikającym z Koranu i Tradycji Proroka Muhammada. Jego zdaniem, święta księga islamu wręcz nakazuje muzułmanom poznawanie rzeczywistości na drodze rozumowej. Co więcej, metoda ta powinna być stosowana zarówno przy badaniu świata zmysłowego, jak i transcendentnego. Awerroes stwierdza, że Koran w żadnym wypadku nie potępia uczonych, a wręcz przeciwnie. Opisuje ich jako ludzi wiary, którzy dochodzą do niej na drodze intelektualnej. Dla uzasadnienia tego twierdzenia odwołuje się do wersetu 7 sury III, który głosi:

On jest tym, który zesłał tobie Księgę. W niej są znaki solidne - one stanowią istotę Księgi - i inne - dwuznaczne. Ci, co w sercach mają skłonność do zwątpienia, postępują za tym, co w niej jest wieloznaczne, poszukują niezgody i dążą do wyjaśnienia tego, co niejasne; lecz nikt nie zna tego wyjaśnienia, tylko Bóg! A ci, którzy są utwierdzeni w wiedzy, mówią: „My wierzymy w niego; wszystko pochodzi od naszego Pana”. Lecz przypominają to sobie tylko ludzie obdarzeni rozumem ${ }^{11}$.

${ }^{11}$ Kor. III, 7. Wszystkie cytaty z Koranu pochodzą z: Koran, przeł. J. Bielawski, PIW, Warszawa 2004. 
Zdaniem tego andaluzyjskiego myśliciela, owi „ci, którzy są utwierdzeni w wiedzy", o których mowa w zacytowanym fragmencie, to właśnie filozofowie.

W opinii Awerroesa, aby nasze poznanie było pewne, musimy posłużyć się rozumowaniem opartym na sylogizmie. W toku swoich rozważań wyróżnia on trzy rodzaje sylogizmu:

- sylogizm demonstratywny,

- sylogizm dialektyczny,

- sylogizm sofistyczny, czyli retoryczny.

Najwyższą wartość ma ta wiedza, którą zdobywa się przy wykorzystaniu rozumowania demonstratywnego, a jest ona dostępna tylko i wyłącznie filozofom. Więc skoro prowadzi ono do uzyskania prawdy, to nie jest $\mathrm{w}$ żadnym wypadku sprzeczne $\mathrm{z}$ objawieniem i religią. Awerroes argumentuje, że jedna prawda nie może być sprzeczna z drugą prawdą. Obie się wzajemnie uzupełniają:

Ponieważ to Prawo jest prawdziwe i wzywa do namysłu prowadzącego do poznania prawdy, my, społeczność muzułmańska, wiemy doskonale, że rozumowanie demonstratywne nie prowadzi do sprzeczności z tym, co zostało zawarte w Prawie. Ponieważ prawda nie sprzeciwia się prawdzie; raczej się z nią zgadza i świadczy o niej ${ }^{12}$.

Natomiast jeśli dochodzi do jakichś sprzeczności między nimi, to ma to miejsce tylko na płaszczyźnie interpretacji pewnych fragmentów Koranu. Jeśli na drodze dowodzenia powstaje antynomia między prawdą osiąganą przez filozofów a dosłownym sensem Prawa, to oznacza, że Prawo dopuszcza interpretację i że konieczne jest dokonanie takiej interpretacji, która doprowadzi do przezwyciężenia powstałej niezgodności.

Awerroes wskazuje, że różnice pomiędzy filozofami i teologami mają swoje źródło w tym, że różnie odczytują oni niektóre fragmenty Koranu. Odnosi się to np. do wersetów, które prezentują wizje eschatologiczne

${ }^{12}$ Averroës, Decisive Treatise. Epistle Dedicatory, przeł. Ch.E. Butterworth, Pravo, Utah 2008, s. 8-9: „Since this Law is true and calls to the reflection leading to cognizance of truth, we, the Muslim community, know firmly that demonstrative reflection does not lead to differing with what is set down in the Law. For truth does not oppose truth; rather, it agrees with and bears witness to it", przekład własny - D.K. 
i opisują życie pozagrobowe, czy też tych, które zawierają obrazy rzeczywistości przed aktem stworzenia. Jego zdaniem teolodzy interpretują je w sposób literalny, natomiast filozofowie doszukują się w nich znaczenia metaforycznego ${ }^{13}$. Podkreśla on jednocześnie, że tylko uczeni, którzy opanowali prawa logiki, mają prawo interpretować święte księgi.

Jeśli chodzi o rozumowanie sylogistyczne, to zauważa on, że bardzo często stawia mu się zarzut, że jest heretycką innowacją, gdyż nie stosowali go pierwsi muzułmanie. Awerroes odpowiada na ten zarzut stwierdzając, że również namysł natury prawniczej wykształcił się dopiero z czasem, a nikt nie określa go mianem heretyckiego, a wręcz przeciwnie: pełni on ważną rolę w życiu intelektualnym muzułmanów. Jego zdaniem, większość popiera intelektualne dociekania oparte na sylogizmie. Wyjątek stanowi tylko wąska grupa literalistów, ale - jak wykazuje - ich stanowisko jest sprzeczne z przekazem koranicznym.

Andaluzyjski filozof zauważa, że skoro Koran nakłada na wiernych obowiązek prowadzenia rozumowego namysłu nad rzeczywistością, to jeżeli ktoś przed nami tego nie czynił, mamy obowiązek takie działanie zapoczątkować, a nasi następcy mają kontynuować nasze dzieło. Natomiast jeśli już ktoś podejmował jakieś kwestie dotyczące otaczającego nas świata, to musimy poznać jego osiągnięcia i odnieść się do nich. Przy czym nie ma zupełnie znaczenia, czy nasz poprzednik podzielał naszą wiarę, czy nie. A ponieważ, jego zdaniem, wszystko, co jest potrzebne do skutecznego posługiwania się rozumowaniem sylogistycznym, zostało dogłębnie przebadane przez myślicieli antycznych, dlatego należy studiować ich dzieła. Proces zdobywania wiedzy o rzeczywistości przebiega podobnie jak poznanie sylogizmu, czyli poprzez kumulowanie wiedzy, którą zdobyły poprzedzające nas pokolenia. Więc skoro antyczni prowadzili badania nad naturą różnych bytów, w tym bytu najwyższego, to powinniśmy skorzystać z ich dorobku. Jak stwierdza:

${ }^{13}$ Zdaniem Awerroesa kwestie literalnego bądź metaforycznego odczytywania Koranu stanowiły główną oś krytyki Al-Ghazalego. Trzy najważniejsze zarzuty, jakie sformułował ten muzułmański teolog, odnosiły się do rzekomego negowania przez filozofów faktu życia po śmierci. Mieli oni jego zdaniem głosić, że świat nie został stworzony, ale jest wieczny, a Bóg nie posiada wiedzy o szczegółach, ale tylko o tym, co jest ogólne. Zob. Averroës, Decisive..., dz. cyt., s. 8-9. 
Z tego wynika, że namysł nad księgami antycznych jest, według Prawa, obowiązkowy, ich cel oraz intencja zawarta w ich pismach jest w znacznym stopniu intencją, do której zachęca nas Prawo ${ }^{14}$.

Awerroes wyróżnia trzy rodzaje poznania: wynikające z dowodzenia, wynikające z dialektyki oraz wynikające z retoryki. Analogicznie do tych trzech dróg uzyskania wiedzy wprowadza on rozróżnienie na trzy grupy ludzi:

- ludzie dowodu, czyli filozofowie;

- ludzie dialektyki, czyli teologowie;

- ludzie retoryki, czyli szerokie masy ludzkie.

Najwyżej stawia on filozofów, gdyż posługują się najbardziej niezawodną z metod, czyli sylogizmem demonstratywnym, dzięki czemu ich wiedza ma najwyższy stopień pewności. Na drugim miejscu umieszcza on teologów, a na samym końcu szerokie masy. Jego zdaniem, zakazywanie uprawiania filozofii jest sprzeczne z religią, gdyż odbija się to negatywnie nie tylko na najlepszych z ludzi, czyli filozofach, ale jest także postępowaniem przeciw Bogu. Taki zakaz jest zły w oczach Absolutu, dlatego że czymś najlepszym dla Niego jest być poznanym w maksymalnym, możliwym dla człowieka, stopniu, a takie poznanie jest dostępne tylko i wyłącznie filozofom, którzy potrafią poprawnie posługiwać się sylogizmem demonstratywnym:

Jednak całkowite zakazywanie książek logicznych [w tym i filozoficznych - dop. D.K.] sprzeciwia się temu, do czego wzywa Prawo, ponieważ jest to coś niewłaściwego w stosunku do najlepszego rodzaju ludzi oraz do najlepszego z istniejących bytów [czyli Boga - D.K.]. W stosunku do najlepszych z istniejących bytów słuszne jest, aby ci, którzy są przygotowani do ich poznania, a stanowią oni najlepszy rodzaj ludzi, poznali je w ich najwyższym stopniu ${ }^{15}$.

${ }^{14}$ Averroës, Decisive..., dz. cyt., s. 6: „From this it has become evident that reflection upon books of the Ancients is obligatory according to the Law, for their aim and intention in their books is the very intention to which the Law urges us", przekład - D.K., M.E. Czernicka.

${ }^{15}$ Tamże, s. 22: „Still, totally forbidding demonstrative books bars from what the Law calls to, because it is a wrong to the best sort of people and the best sort of existing things. For justice with respect to the best sort of existing things is for them to be 
Innym kontrargumentem przeciwko zarzutom Al-Ghazalego, jaki przytacza Awerroes, jest to, że sami teolodzy posługują się logiką w celu obrony swoich twierdzeń. Wskazuje, że argumenty przeciw filozofom, które sformułował Al-Ghazali, mają charakter czysto filozoficzny.

\title{
4. DYSKUSJA IBN AL-MUNADŻDŻIMA Z CHRZEŚCIJANAMI
}

Muzułmanie sięgali także po logikę podczas dyskusji z wyznawcami innych religii w celu przekonania ich o autentyczności objawienia, jakie otrzymał prorok Muhammad. Przykładem takiego postępowania jest list Ibn al-Munadżdżima, w którym autor stara się przekonać swoich dwóch przyjaciół chrześcijan do uznania prawdziwości islamu ${ }^{16}$.

Swoje rozważania zaczyna od stwierdzenia, że tylko głupiec odrzuca to, co zostało udowodnione za pomocą niezawodnych metod, jak również nie można zanegować prawdziwości tego, co jest uznane za prawdę przez wszystkich ludzi. Przestrzega on również przed zbyt pochopnym odrzuceniem przedstawionych przez niego argumentów, gdyż wszelkie rozumowanie powinno odbywać się w spokoju i skupieniu. Podczas badania wszelkich kwestii powinniśmy starać się zachować jak najwięcej obiektywizmu w ocenie, dlatego zaleca on, abyśmy starali się odizolować się od wszelkich sugestii oraz zewnętrznych wpływów. Taka postawa ma spowodować, że dowód, który przedstawia filozof, stanie się jasny i zrozumiały. W swoim liście pisze o tym w następujący sposób:

\begin{abstract}
Albowiem pozostaje bezowocnym rozważanie spekulatywne dla badacza oraz rozmyślanie dla myśliciela, jeśli nie towarzyszy temu pokój serca wolnego od wszelkich dewiacji oraz serce czyste od złych skłonności i wolne od przyzwyczajeń i społecznych uwarunkowań, w których było uwikłane. [...] Powinien oddawać się temu, co doprowadzi go do
\end{abstract}

cognized to their utmost degree by those prepared to be cognizant of them to their utmost degree, and these are the best sort of people”, przekład - D.K., M.E. Czernicka.

${ }^{16}$ Sam Ibn al-Munadżdżim jest postacią enigmatyczną. Żył on w IX wieku i pochodził z rodu Banu Munadżdżim, którego przedstawiciele byli astrologami na dworze abbasydzkim. Niestety, nie wiemy dokładnie, kim był autor zachowanego listu. Jego adresatami byli Qusta Ibn Luqa oraz Hunayn Ibn Ishaq. Zob. Korespondencja między chrześcijaninem a muzułmaninem, przeł. J.A. Szymańczyk, Wydawnictwo WAM, Kraków 2005. 
ostatecznego wyzwolenia, czuwając, aby oddalić od siebie rzeczy, które wyprowadzić by go mogły na manowce i uniemożliwić mu dokonanie dobrego wyboru ${ }^{17}$.

Ibn al-Munadżdżim zauważa, że istnieją takie fakty, których prawdziwości nie możemy zanegować. Wśród nich wymienia na przykład jednomyślność co do tego, że Mojżesz czy Jezus to postacie historyczne ${ }^{18}$. Podobna zgodność opinii odnosi się co do historyczności Muhammada. Płaszczyzną sporu jest to, czy byli oni prorokami, czy też nie. Kryterium uznania kogoś za proroka, zdaniem tego myśliciela, jest to, że Bóg za jego pomocą przekazuje ludziom pewne cudowne dowody, które mają potwierdzać ich misję proroczą. Wobec tego gdy ktoś czyni tego typu znaki, to należy mu wierzyć. Ibn al-Munadżdżim podkreśla, że nie ma znaczenia wielkość cudu - wystarczy, że to, czego dokonał prorok przy pomocy Boga, przekracza ludzkie możliwości:

Jeśli zatem Posłańcy czynią znaki, których nie są w stanie uczynić żadne moce ziemskie, trzeba im uwierzyć i przestać zaprzeczać. I nie ma znaczenia, czy znak jest skromny, czy pełen splendoru, bo jeśli żaden uczony nie jest w stanie uczynić podobnego, należy go uznać. I tak na przykład dwóch Posłańców, jeden z nich wskrzesiłby z martwych wszystkich mieszkańców Ziemi, a drugi jakiekolwiek zwierzę, sprowadzałoby się to do tego samego z perspektywy tych, którzy znajdują się na poziomie natury ${ }^{19}$.

Przechodzi on następnie do przedstawienia szeregu argumentów, które mają potwierdzać misję proroczą Muhammada. Jednym z nich jest to, że doprowadził do ucywilizowania Arabów, którzy przed rozpoczęciem przez niego działalności religijnej byli dzicy i barbarzyńscy. Ma to dowodzić,

${ }^{17}$ List Ibn al-Munadżdżima, [w:] Korespondencja..., dz. cyt., s. 28.

${ }^{18} \mathrm{~W}$ dzisiejszych czasach kwestia historyczności Jezusa nie jest już tak oczywista. Spotkać można myślicieli ateistycznych, którzy podważają nie tylko, że był Bogiem, ale także to, że w ogóle istniał. Przykładem takiego podejścia jest stanowisko Michela Onfraya, który w Traktacie ateologicznym, przytacza szereg argumentów, że osoba Jezus jest wytworem Pawła z Tarsu i pierwszych chrześcijan. Zob. M. Onfray, Traktat ateologiczny, przeł. M. Kwaterko, PIW, Warszawa 2009.

${ }^{19}$ List..., dz. cyt, s. 29. 
że był on najbardziej inteligentnym z ludzi, co potwierdza fakt, w jaki sposób administrował gminą muzułmańską i w jaki sposób uprawiał politykę. Według tego filozofa, nikt nie robił tego równie dobrze jak on. Inną przesłanką przemawiającą za tym, że Muhammad faktycznie był prorokiem, jest to, że zdołał on przekonać do islamu własnych współplemieńców. A ponieważ jest niemożliwe przekonać ludzi do tego, aby uznali kogoś ze swoich rodaków za proroka, to musiał on posiadać wsparcie Boga, skoro jego działalność zakończyła się sukcesem:

\begin{abstract}
Wszyscy ludzie, uczeni i nie uczeni, jednogłośnie zgadzają się co do faktu, iż jest niemożliwe i nieprawdopodobne w naturalnym porządku rzeczy, aby człowiek zdrowy na umyśle i normalnie przez naturę uposażony, mógł przemówić do narodu, w którym urodził się, wzrastał, z którego wyszedł i wśród którego spędził całe swoje życie, w ich własnym języku, albowiem wszystkie słowa brane pojedynczo były im znane, ale uczynić to $\mathrm{w}$ takiej kompozycji znaczeniowej, że mowa jego wyrasta ponad wszystko, co dotychczas słyszeli ${ }^{20}$.
\end{abstract}

Ibn al-Munadżdżim odwołuje się także do fragmentów Koranu, które opisują fakt, że Muhammad rzucił wyzwanie Arabom, aby przynieśli surę podobną do tej, którą objawił mu Bóg ${ }^{21}$. Pomimo że wśród nich było wielu wybitnych poetów, nikt takiej sury nie przyniósł. Jego zdaniem, Muhammad nie odważyłby się na tego typu posunięcie, gdyby nie był absolutnie pewny, że nikt nie podoła temu zadaniu. A ponieważ żaden człowiek nie może dysponować wiedzą o przyszłości i o tym, co niewidzialne, gdyż posiada ją tylko i wyłącznie Bóg, to skoro Muhammad rzucił to wyzwanie, to wiedzę o ostatecznym rozstrzygnięciu musiał posiadać od Boga. Przekazał on również wiele wizji eschatologicznych, które nie są dostępne zwyczajnym ludziom. Więc ponieważ dysponował wiadomościami, których źródłem mogła być tylko Transcendencja, to należy przyjąć, że Muhammad był faktycznie prorokiem.

Ibn al-Munadżdżim argumentuje również, że gdyby ktoś przyniósł surę, której zażądał Muhammad, to byłby on całkowicie pokonany i zdyskredytowany. Jak pisze:

\footnotetext{
${ }^{20}$ Tamże, s. 38.

${ }^{21}$ Zob. Kor. II, 23.
} 
Muhammad (Pokój nad Nim!) unicestwiłby swą misję, zaprzeczyłby swojemu dowodowi, spowodowałby oddalenie się od niego jego bliskich i ucieczkę tych, którzy za nim poszli, dolałby oliwy do ognia złośliwości swoich nieprzyjaciół, ściągnąłby na siebie niesprawiedliwość, gdyż mając nad nimi przewagę, osiągnęliby, dzięki temu co czynił, swój ostateczny cel i ostateczne pragnienie ${ }^{22}$.

Nie wyznaczył on swoim przeciwnikom granicy czasu, do której mają wypełnić zadanie, ani też nie ukrywał przed nimi Koranu. Mimo to nikt nie ułożył sury podobnej do sury koranicznej. Według Ibn al-Munadżdżima jest to dowód na to, że Koran ma Boskie pochodzenie. Tezę tą potwierdza również fakt, że przeciwnicy walczyli z Muhammadem i pierwszymi muzułmanami zbrojnie, a nie ideologicznie. A jak zauważa ten filozof, gdyby islam nie był prawdziwy, to pokonanie muzułmanów na gruncie ideowym nie wymagałoby żadnego wysiłku. Więc wyciąga on z tego faktu wniosek, że ponieważ politeistyczni Mekkańczycy wiedzieli, że islam jest prawdziwy, to woleli rozpocząć działania wojenne przeciw muzułmanom.

\section{PODSUMOWANIE}

Mimo że przedstawione $\mathrm{w}$ artykule przykłady stanowią tylko pewien wycinek metody argumentowania z odwoływaniem się do racji logicznych przez myślicieli muzułmańskich ${ }^{23}$, to ukazują one, w jaki sposób muzułmanie przejęli i zasymilowali dorobek antycznych filozofów ${ }^{24}$. Nawet

${ }^{22}$ List..., dz. cyt., s. 42.

${ }^{23}$ Jednym z ważniejszych sporów na gruncie myśli muzułmańskiej był spór między logikami a gramatykami, którego osią była kontrowersja: która z nauk - gramatyka czy logika - lepiej nadaje się do badania języka. Al-Farabi twierdził, że tylko za pomocą logiki można dotrzeć do głębokich struktur języka, a gramatyka może zaproponować jedynie zasady dla jego struktur powierzchniowych. Logika byłaby w stanie ustalić podstawowe reguły, które - jako uniwersalne - byłyby wspólne dla każdego języka, natomiast gramatyka odnosiłaby się tylko do konkretnego języka. Za tymi sporami stoi pytanie, która z nauk lepiej nadaje się do wyjaśniania Koranu, którego język uznaje się za cudowny i niemożliwy do naśladowania. Zob. szerzej: O. Leaman, dz. cyt., s. 17-18; J. Danecki, dz. cyt., passim.

${ }^{24}$ Innym przykładem obecności logiki w myśli filozofów muzułmańskich jest dzieło Awicenny Księga wiedzy. Ibn Sina, podążając za przykładem Arystotelesa, swoje 
Al-Ghazali, który sformułował wiele poważnych zarzutów wobec muzułmańskich „uczniów” Arystotelesa, takich jak Al-Farabi czy Awicenna, potrafił docenić i wykorzystać idee, jakie zawarł Stagiryta w swoim Organonie. Pomimo że w polemice, jaką prowadził z isma'ilitami, wyraźnie pobrzmiewa osobista niechęć wobec przedstawicieli tego ruchu, to swoją argumentację stara się oprzeć na zasadach wnioskowania logicznego.

Podobnie czyni Awerroes, gdy usiłuje odeprzeć ataki Al-Ghazalego wobec filozofów. Te, jak i inne przykłady świadczą o wysokiej kulturze intelektualnej muzułmanów okresu średniowiecza, która przejawiała się nie tylko na gruncie filozofii, ale także w innych licznych dziedzinach kultury i nauki. A jak wskazują argumenty Awerroesa, w samym Koranie znajdują się wersety, które zachęcają do zgłębiania wiedzy i poznawania jej na drodze racjonalnych dociekań.

Najciekawszym - moim zdaniem - przykładem wykorzystania logiki jest list Ibn al-Munadżdżima. Zarówno zawarte w nim argumenty, jak też odpowiedzi na nie stanowią bardzo ciekawy przykład dialogu religijnego prowadzonego pomiędzy chrześcijanami a muzułmanami w IX i X wieku. Pokazuje on, że przedstawiciele różnych religii mogą dyskutować, odwołując się do racji rozumowych i z poszanowaniem argumentów drugiej strony. Bassam Tibi w swojej monografii Fundamentalizm religijny wskazuje między innymi na mistyczne rozumienie religii jako miłości do Boga, a więc tego elementu, który można wykorzystać jako dobrą metodę przezwyciężania ideologii fundamentalistycznych ${ }^{25}$. Natomiast przykład średniowiecznej korespondencji pomiędzy muzułmanem i chrześcijanami pokazuje, że obok mistyki również logika może stanowić narzędzie pozwalające zbliżyć do siebie różne wyznania.

rozważania dotyczące fizyki i metafizyki poprzedza wykładem logiki. Zob. Awicenna, Księga wiedzy, przeł. B. Składanek, Wydawnictwo Naukowe PWN, Warszawa 2010.

${ }^{25}$ Zob. B. Tibi, Fundamentalizm religijny, przeł. J. Danecki, PIW, Warszawa 1997. 


\section{LOGIC ARGUMENTS IN THE MEDIEVAL MUSLIM PHILOSOPHY AND THEOLOGY: AL-GHAZALI, AVERROES, IBN AL-MUNADŻDŻIM}

\section{SUMMARY}

Philosophical legacy of ancient Greeks greatly influenced the shaping of Medieval Islamic thought. Especially popular were writings of Aristotle, particularly his logical works. Muslims very quickly noticed that logic is a very practical tool, both in discussions with non-Muslims, as well as polemics within Islam itself. This article focuses on three thinkers: Al-Ghazali, Averroes and Ibn al-Munajjim.

Al-Ghazali's ideas exemplify how logic was used in theological disputes within Islam itself. Averroes, in turn, in one of his major works „The Decisive Treaty", tries to refute accusation aimed at impiety of philosophers. Ibn Rushd shows that philosophy is not contrary to the principles of faith but just opposite. He states that The Quran encourages to learn and deepen the philosophy, because it is the best way to cognition of the truth and it based on syllogistic deduction. Concluding, the article presents how logic was used in disputes with non-Muslims by referring to Ibn al-Munajjim letter.

\section{KEYWORDS}

certain knowledge, interreligious dialogue, Islam, ismailism, logic theology, Al-Ghazli, Averroes, Ibn al-Munajjim 